\title{
The Colonization and Prosperity of National Traditional Sports Culture from the Perspective of Cultural Self-confidence
}

\author{
Dongzhi Tian \\ College of Education Science \\ Bohai University \\ Jinzhou, Liaoning, China
}

\author{
Tao $\mathrm{Xu}^{*}$ \\ College of Physical Education \\ Bohai University \\ Jinzhou, Liaoning, China
}

\begin{abstract}
The assertion of cultural self-confidence has opened up a new path for the development of China's national traditional sports culture. Based on the perspective of cultural self-confidence, this paper uses literature and logic analysis to illustrate the development dilemma of the current national traditional sports culture and how to colonize and inherit under the torrent of the times. In the face of the impact of today's sports globalization, we should advance with the times, refuse to hold on to the deficiencies, use the frontiers of modern science and technology to colonize and prosper the national traditional sports culture, let China compete for more discourse power in competitive sports, and let Chinese characteristics Socialist culture is rooted in the hearts of every Chinese.
\end{abstract}

Keywords-Cultural self-confidence; national traditional sports; colonization

\section{INTRODUCTION}

The national traditional sports culture has a long history and condenses the wisdom of the ancient Chinese people. With the changes of the times and the impact of the Western competitive sports culture, many traditional Chinese sports are gradually being forgotten and abandoned.

In the report of the 19th National Congress of the Communist Party of China, Xi Jinping proposed to strengthen cultural self-confidence and promote the prosperity of socialist culture. Without a high degree of cultural self-confidence and no cultural prosperity, there would be no great rejuvenation of the Chinese nation. We must adhere to the road of development of socialist culture with Chinese characteristics, stimulate the cultural innovation of the entire nation, create vitality, and build a strong socialist culture [1].

National traditional sports culture belongs to an important branch of socialist culture with Chinese characteristics. Prospering and developing the national traditional sports culture is conducive to the socialism culture with Chinese characteristics going to the world. Therefore, based on the perspective of cultural self-confidence, it is of great significance to colonize and prosper and develop China's national traditional sports culture.

\section{Cultural CONFIDENCE-The Foundation OF SOCIALIST CULTURE WITH CHINESE CHARACTERISTICS}

In his important speech of "September 26", General Secretary Xi Jinping pointed out that "socialism with Chinese characteristics is the theme of all theories and practices of the party since the reform and opening up", and requires the whole party to "firmly establish the road of self-confidence and theoretical self-confidence of socialism with Chinese characteristics. Institutional self-confidence and cultural selfconfidence ensure that the cause of the party and the country always advances in the right direction [2]. In the "four selfconfidence", cultural self-confidence is a more basic, broader, deeper self-confidence, more basic, deeper, and more lasting power. Cultural self-confidence has been repeatedly emphasized since the 18th National Congress, and its importance is self-evident. Cultural self-confidence also leads to many in-depth discussions through the perspective of socialism with Chinese characteristics [3].

From the long history of China's 5,000 years of history, gathering all its excellent cultures into a river has become the socialist culture with Chinese characteristics. The revolutionary and socialist advanced culture created in the practice of casting and transformation is rooted in the great practice of socialism with Chinese characteristics. Self-confidence with socialism with Chinese characteristics includes three kinds of selfconfidence: the first is the self-confidence of the national cultural tradition, the second is the self-confidence of the Chinese revolutionary cultural tradition, and the last is the selfconfidence of the foreign cultural tradition. This last selfconfidence is to Cultural self-confidence based on a dialectical position is not a complete "westernization" [4].

The status of the national traditional sports culture with a long history of the Chinese nation has been highlighted in the establishment of cultural self-confidence. Nowadays, the development of China's national traditional sports culture faces many difficulties. How to colonize and prosper China's national traditional sports culture is establish a problem that needs to be solved urgently in the concept of cultural selfconfidence.

Phased Achievements of Humanities and Social Sciences Research of Liaoning Provincial Department of Education in 2019 


\section{NATIONAL TRADITIONAL SPORTS CULTURE-AN IMPORTANT ROLE OF THE PROMOTION OF CULTURAL SOFT POWER}

Strong economic strength, strong military power, advanced modern technology, and attractive culture are the four signs that a big country should have. Culture is also an important factor in the prosperity of the country and the enhancement of national belonging and cohesion. In the "Declaration on Cultural Diversity", UNESCO stated: "Development should be defined by cultural concepts. Cultural prosperity is the highest goal of development [5]." National traditional sports culture is the foundation of China's sports culture. Cultural selfconfidence and the promotion of cultural soft power have a key role.

The national traditional sports culture has a long history, rich sports and competition forms. The value of national traditional sports is also multifaceted. Only by recognizing the value, it is meaningful to colonize and prosper national traditional sports.

\section{A. Traditional sports value}

What is an intangible cultural heritage, it refers to the various practices, performances, expressions, knowledge systems and skills of related groups, collectives, and sometimes cultural heritage as well as related tools, objects, crafts and cultural sites. The national traditional sports culture is different from the material cultural heritage. It is the basis for the continuous development and inheritance of mankind. As far as China's national traditional sports events are concerned, they bear the historical heritage of the Chinese nation, and the most important value is the cultural value.

\section{B. Audience value}

National traditional sports, the audience is people, for each person participating in sports, fitness value and entertainment value is valued by the athletes. Taking martial arts as an example, people improve their coordination, flexibility and strength by practicing martial arts. And after the practice, through the release of sweat, the whole body is happy. It not only enhances one's physical quality, enhances the quality of life, but also fits the connotation of national fitness in China.

\section{Value of international exchange}

At present, Western competitive sports occupy a dominant position in international exchanges. China's lack of nationality in international large-scale events such as the Olympic Games has indirectly led to a lack of strength in formulating rules and encountering unfair treatment. The lack of sports discourse rights.

In the 1970 "Ping Pong Diplomacy" incident (also known as "small ball turning big ball"), Mao Zedong successfully promoted normal exchanges with the United States through table tennis. Nowadays, the prosperity and development of China's national traditional sports has important value. It can not only enhance China's right to speak in competitive sports, but also enable other countries to understand China more.

\section{THE DILEMMA OF THE DEVELOPMENT OF NATIONAL TRADITIONAL SPORTS}

\section{A. Cultural Alienation in the Form of Globalization}

The globalization of sports has seriously impacted the national sports culture. Nowadays, the status of Western competitive sports culture cannot be shaken. The main body of the Olympic movement is also based on Western sports. From the perspective of various sports cultures in China (competitive sports, mass sports), it has an indelible oppressive effect. Take the National Games as an example. Except for martial arts, other competitions are mostly Olympic events [6]. This phenomenon is also common among Chinese youth groups. No matter whether it is in primary or secondary schools or college physical education classes, students basically choose sports such as football and basketball to exercise. There are very few choices for traditional sports such as martial arts and Tai Chi.

\section{B. Gradually falling subject}

At present, after the transition of the national traditional sports from the private to the official, the people' s sense of existence has gradually disappeared, replaced by rich tournament bonuses and gradually westernized competition rules. With the restrictions on the conditions of participation, the participation of non-professionals has gradually declined, and the subject of inheriting the national culture has gradually faded out of the stage, so the traditional national sports have lost their meaning. Under the impact of Western culture, only those that meet the East and the West Cultural projects can survive and develop, and in the process of catering to Western culture, the traditional national sports culture has lost its own things.

\section{Dusty content and form}

"56 ethnic groups, 56 families", China has as many as 56 ethnic groups, and the national history is long, so our national traditional sports culture will be diverse. It is precisely because of its complexity, diversity, and the inconsistency of rules that have become the embarrassment of the development of traditional national sports culture.

The diversity of rules and the staffing of the venues have made it impossible to unify and integrate the traditional sports, which has led to the failure of many excellent projects. The traditional sports of ethnic minorities have not been better developed. The reasons for this are many aspects. One of them is that the traditional sports of ethnic minorities are not fully reorganized, and their rich cultural heritage and national characteristics have not been better developed. And the essence is also excessively stripped, blindly magnifying the competitiveness of the project, making its development gradually align and close to competitive sports, while the cultural and artistic nature is gradually reduced, so it is included in the "faster", "higher" and "Strong" in the discourse and value system of world civilization [7]. 


\section{The Colonization AND PROSPERITY OF NATIONAL TRADITIONAL SPORTS CULTURE FROM THE PERSPECTIVE OF CUltural SELF-CONFIDENCE}

A. Under the guidance of cultural self-confidence, the coloniz ation of traditional national sports culture in winter

The term colonization originally meant the process by which plant propagules germinated, grew and reproduce in a new area. For the traditional sports culture of the nation, it means that a traditional sports project has been discovered and spread to all parts of the country, the process of development and inheritance.

1) Taking the 2022 Beijing Winter Olympics as an opportunity to expand the traditional sports culture of the colonial

From February 4th to 20th, 2022, the 24th Winter Olympic Games will be held jointly by Beijing and Zhangjiakou. This is also the third Olympic Games event successfully applied for in China. It is also the first time that China has hosted the Winter Olympics. The snow and ice sports will sweep through the two cities of Beijing and Zhangjiakou.

The Winter Olympics, which collides with the global sports culture exchange, serves as a platform to make our traditional sports 'going out' better. At that time, the global media will focus on the Winter Olympics held in China. We can pass the traditional snow and ice movements of our country through the opening ceremony of the Winter Olympics, such as "ice play" and "ice ball" . The opening ceremony is the most special form of performance for each Olympic event. It promotes the traditional Chinese ice culture through the performance of the show. This form not only enables foreign friends to understand China's national traditional sports culture but also enhances China. The people's sense of national belonging, so that the socialist culture with Chinese characteristics is better rooted in the hearts of every Chinese, so that every Chinese can consciously undertake the mission of discovering and inheriting the traditional sports culture of the winter.

2) Rational use of e-sports industry - promoting cultural self-confidence to the cultural consciousness

E-sports is a worldwide cultural phenomenon that has risen rapidly since the beginning of the new century. It attracts a large number of participants and viewers, and its main body is young people. Under the influence of various factors, this cultural form is sweeping the world and has an extremely wide and profound social impact. In October 2017, the International Olympic Committee announced at the 6th Summit that it agreed to consider e-sports as a "sports activity" [8].

From the current influence, e-sports is undoubtedly the most attractive sport that attracts young people's attention. In the League of Legends global competition that ended shortly before, the ratings of China's live broadcast platforms reached 100 million views on the final day, and e-sports projects have become an indispensable part of sports culture.

Cooperate with the top game production teams in China to combine traditional national sports and video games to create a mobile game suitable for the general public. In the process of game entertainment, the competition rules and venues of traditional sports events can be better portrayed in the player's impression. The Chinese mobile game has received much attention from the world. The well-known king glory has been loved by friends at home and abroad. Many pirate glory is prevalent in all countries of the world. Taking advantage of the influence of China's mobile games in the world, it is better to let our national traditional sports culture 'go out'. We can learn from the League of Legends game to join the National Games performance project, and strive to bring our national traditional sports culture into the Olympics through e-sports, occupy a place in the collision of world culture, and truly obtain the diplomatic discourse power of sports culture.

\section{B. The prosperity of national traditional sports culture under} the guidance of cultural self-confidence

1) The combination of ideological and moral construction and folk sports culture

In the report of the 18th National Congress of the Communist Party of China, "moral construction" was included in the "socialist core value system", which put forward a new era proposition for sports morality construction.

Professor Cao Jingchuan proposed: "Sports ethics is the code of conduct and norms that sports practitioners and the general public should follow in sports activities." From a philosophical perspective, sports ethics belongs to the superstructure and ideology category [9]. As a cultural soft power, sports ethics is the guarantee for China's sports to be at the forefront of the international arena, and it is also strong support for building a "sports power" dream.

For the younger generation of our country, especially the primary and middle school students, they are the main body of socialist culture with Chinese characteristics, and they are especially important for them to carry out the necessary sports moral construction. Only by cultivating the ideology of consciously inheriting and protecting China's traditional sports culture from an early age can China's national traditional sports culture flourish.

\section{2) Establishing a campus sports league system}

Yang Yang, a member of the National Committee of the Chinese People's Political Consultative Conference and the short-staple speed skating champion of the Winter Olympics, said: "There are many opportunities for young people to participate in physical exercise in primary and kindergarten stages. There are also many types of sports participating and learning, but they are entering secondary schools and many students have sports activities. There was a cliff-like decline in participation."

Although the examination-oriented education in our country has changed in recent years, the emphasis on school sports is still insufficient, especially in the traditional sports of the nation. Therefore, junior high school should adopt a class system based on class for Taijiquan or martial arts. In the case of colleges and universities, the colleges and universities can carry out dragon boat leagues based on groups, and the martial arts league system with individual units can improve the students' physical fitness and at the same time prosper and develop China's national traditional sports culture. 


\section{CONCLUSION}

Cultural self-confidence and the inheritance and development of national traditional sports culture complement each other. The assertion of cultural self-confidence is conducive to China's introduction of a series of policies to explore, protect and inherit the traditional Chinese sports culture. The prosperity and development of China's national traditional sports culture promote cultural self-confidence in the opposite direction. We should respond to the call, launch the slogan of national fitness, accelerate the goal of building a strong sports country, and strive to hold an ingenious Winter Olympics so that China's national traditional sports culture can be better integrated into the world sports culture. Establishing the concept of taking me as the mainstay and eclecticism, aiming at the forefront of modern science and technology, keeping up with the trend of the times and developing our country's traditional sports culture. Only in this way can our national traditional sports culture be innovated in order to adapt to the trend of the times and be better. prosper.

\section{REFERENCES}

[1] Jinping Xi. Decisive victory to build a well-off society in an all-round way to win the great victory of socialism with Chinese characteristics in the new era. Beijing: People's Publishing House, 2017.
[2] Jinping Xi. Firmly establish the confidence of socialism with Chinese characteristics. Zhejiang Daily, 2017.

[3] Jinping $\mathrm{Xi}$. won the victory and built a well-off society in an all-round way to win the great victory of socialism with Chinese characteristics in the new era. People's Daily, 2017.

[4] Jiangping Shen. Three kinds of "cultural traditions" in the construction of cultural self-confidence.Journal of Fujian Provincial Committee Party School of CPC, vol.10, pp.104-109, 2018.

[5] Jinxiang Bai, Yi Wan, Pelin Long. Exploring the Roots of Traditional Sports Culture Inheriting the Spirit of Modern Sports Civilization: A Review of Research on National Traditional Sports from the Perspective of Intangible Cultural Heritage. Journal of Beijing Sport University, vol.01, pp.119-128, 2017.

[6] Wei-ping LI, Zhi-hui WANG. SWOT Analysis of the Development of National Traditional Sports Culture in China. Journal of Sports and Science, vol.06, pp.28-32, 2011.

[7] Chunjia Jia, Shuangling Li, Baofeng Zhu, Hong Zhu, et al. The Origin, Characteristics and Development Countermeasures of Chinese Ice and Snow Sports Culture.Journal of Harbin Sport University, vol.03, pp.5156, 2017.

[8] Yue Yang. Research on E-sports and E-sports Industry in the New Era.China Sport Science, vol.04, pp.8-21, 2018.

[9] Guanghu Wang. Planning and Moving: Where Does China's Sports Ethics Construction Go?-A Brief Comment on Professor Cao Jingchuan's Book "China's Sports Ethics Construction in the Trend of Professionalization". Sports Research and Education, vol.03, pp.46-47, 2018 